\title{
Rice husks as a microbial source for wastewater treatment
}

\author{
Jair J. João ${ }^{1}$, Luana Locks ${ }^{1}$, José L. Vieira ${ }^{1} \&$ Eder A. Lucia $^{1}$ \\ ${ }^{1}$ Universidade do Sul de Santa Catarina/Centro Tecnológico, Campus Tubarão, Tubarão, SC, Brasil. E-mail: jair.joao@unisul.br (Corresponding author) \\ - ORCID: 0000-0001-5645-6339; luana.eqm@gmail.com - ORCID: 0000-0003-3410-8055; jlvieira1994@uol.com.br - ORCID: 0000-0002-7943-5730; \\ eder.lucia@bol.com.br - ORCID: 0000-0002-0011-7538
}

\begin{abstract}
Water contaminated with organic carbon and nitrogen compounds is one of the most important water problems in the contemporary world. The main problems related to the discharge of these compounds into natural environments are eutrophication and oxygen depletion. In view of this scenario, the objective of this work was to assess the use of rice husks for the production, growth, and propagation of microorganisms, and the use of these microorganisms for the removal of organic matter and nitrogen compounds in wastewater treatments. The following treatments were evaluated: industrial wastewater (IW), IW + rice husks, IW + sawdust and IW + dried leaves of trees. The effluent was treated with $3 \%\left(\mathrm{v} \mathrm{v}^{-1}\right)$ inoculum of microorganisms obtained from rice husks as substrate, applied in a batch system. A solution of $30 \mathrm{mg} \mathrm{L}^{-1}$ of N-NO${ }_{3}$ containing $3 \%\left(\mathrm{v} \mathrm{v}^{-1}\right)$ of microorganisms obtained from rice husks was used as substrate to evaluate the reusability and performance of $\mathrm{N}_{-} \mathrm{NO}_{3}$ removal. Higher microbial growth was found when the rice husks was used as substrate. The chemical oxygen demand, biochemical oxygen demand, total nitrogen, and total solid contents were reduced above $80 \%$. The kinetic evaluation showed that total nitrogen and nitrate can be reduced by up to $80 \%$ after $72 \mathrm{~h}$. Moreover, the reuse test showed the stability of the microbial activity after 7 days of use. This study showed that rice husks is an interesting and more sustainable source of carbon for microbial growth, with effective use in wastewater treatments.
\end{abstract}

Key words: pollutants, substrate, nitrogen removal, nitrate

\section{Utilização da casca de arroz como fonte microbiana para tratamento de efluentes}

RESUMO: A água contaminada com carbono orgânico e com compostos nitrogenados se apresenta como um dos mais importantes problemas hídricos do mundo contemporâneo. Os principais problemas relacionados à descarga desses compostos no ambiente natural são a eutrofização e a depleção de oxigênio. Diante desse cenário, o objetivo deste estudo foi utilizar a casca de arroz para geração, crescimento e propagação de microrganismos, e posteriormente, utilizar no tratamento de águas residuais para remoção de matéria orgânica e compostos de nitrogênio. Primeiramente, foram avaliados os seguintes tratamentos: água residual industrial (ARI), ARI + casca de arroz, ARI + serragem e ARI + folhas secas de árvores. Para o tratamento de um efluente real, $3 \%\left(\mathrm{v} \mathrm{v}^{-1}\right)$ de inóculo de microrganismos obtidos da casca de arroz como substrato foi aplicado em um sistema de batelada. Uma solução de $30 \mathrm{mg} \mathrm{L}^{-1}$ de $\mathrm{N}-\mathrm{NO}_{3}$ contendo $3 \%\left(\mathrm{v} \mathrm{v}^{-1}\right)$ de microrganismos obtidos da casca de arroz como substrato foi utilizada para avaliar a reutilização e desempenho da remoção de $\mathrm{N}-\mathrm{NO}_{3}$. Verificou-se maior crescimento microbiano quando a casca de arroz foi utilizada como substrato. A demanda química de oxigênio, a demanda bioquímica de oxigênio, o nitrogênio total e os sólidos totais foram reduzidos acima de $80 \%$. Os estudos cinéticos mostraram que o nitrogênio e o nitrato total podem ser reduzidos em até $80 \%$ após 72 h. Além disto, o teste de reutilização demonstrou a estabilidade da atividade microbiana após sete dias de utilização. Este estudo mostrou que a casca de arroz é uma fonte interessante e mais sustentável de carbono para o crescimento microbiano, com uso efetivo no tratamento de águas residuais.

Palavras-chave: poluentes, substrato, remoção de nitrogênio, nitrato 


\section{INTRODUCTION}

Economic development and industrialization pose serious risks to drinking water availability on the planet (João et al., 2018). Contaminated water with organic carbon and nitrogen compounds is one of the most important water problems in contemporary world (Khan \& Malik, 2019). The main problems related to the discharge of these compounds into natural environments are water eutrophication and oxygen depletion (Hulle et al., 2010).

Increasing water contamination by nitrogen-containing compounds requires special attention since there is a global concern about polluted water with ammonia, nitrite, and nitrate ions (Bartucca et al., 2016; Shen et al., 2016). This is probably the most widespread contaminant in groundwater because of the high solubility of nitrate in water, and is a serious risk to the adequate supply of drinking water and to human health (Costa et al., 2018). Organic and nitrogenous pollutants from wastewater are generally removed through biological treatments (Huang et al., 2017). This process involves transformation of dissolved and suspended organic contaminants into biomass and release of gases (Low \& Chase, 1999).

Agricultural residues, such as rice husks, can be an abundant and cheap source of carbon and has been widely studied as a medium for the production, fixation and propagation of microorganisms (Akinyele \& Adetuyi, 2005; Yang et al., 2015). However, most studies do not show the use of these microorganisms in wastewater treatments. Thus, the objective of this study was to assess the use of rice husks for the growth and propagation of microorganisms, and the use of these microorganisms for the removal of organic matter and nitrogen compounds in wastewater treatments.

\section{Material ANd Methods}

The study was carried out using rice husks collected at an agricultural cooperative of rice processing (COPAGRO), in southern state of Santa Catarina, Brazil. The microorganisms were immobilized in rice husks or suspended in solution. All chemical reagents used in analytical degree and solutions were prepared with deionized water obtained by the Millipore Milli-Q system.

The wastewater samples were collected monthly over one year at the COPAGRO wastewater treatment station. The wastewater was sampled according to the NBR 9897 - Planning of liquid effluent sampling and receiving bodies) (ABNT, 1987a), and NBR 9898 - Preservation and sampling techniques of liquid effluents and receiving bodies (ABNT, 1987b).

The rice husk composition, regarding protein, extractives, ash, and moisture contents was determined in triplicate by laboratorial chemical analysis at the Universidade do Sul de Santa Catarina, Tubarão, SC, Brazil. Cellulose, hemicellulose, and lignin contents in the rice husks were determined using the van Soest method (Soest et al.,1991).

The microorganisms were obtained from the following biomass residues: industrial wastewater (IW), IW + rice husks, IW + sawdust, and IW + dried tree leaves. The experiment was conducted by placing $200 \mathrm{~mL}$ of water in a sterilized erlenmeyer and $15 \%$ wb of each biomass was added. The tests were performed without additional source of carbon and nitrogen.

The inoculum prepared was kept in an oven for $72 \mathrm{~h}$ at $37^{\circ} \mathrm{C}$ before the counting of colony forming units (colony forming units - CFU); $1 \mathrm{~mL}$ was taken every $24 \mathrm{~h}$ for dilutions of $1: 10^{3}$ and $1: 10^{6} ; 1 \mathrm{~mL}$ was seeded on Mueller-Hinton agar plates with a sterile Drigalski loop. The dilution was spread evenly across the plate and incubated in an oven for $24 \mathrm{~h}$ at $37^{\circ} \mathrm{C}$. The colonies were then manually counted on the plates. Eq. 1 was used to calculate the number of CFUs $\left(\mathrm{CFU} \mathrm{mL} \mathrm{m}^{-1}\right)$ :

$$
\mathrm{CFU}=\frac{\text { Number of colonies }}{\text { Dilution }}
$$

The sowing on Mueller-Hinton agar allowed the observation of colony growth, which was separated from successive sowing on Macconkey and Blood agar plates to obtain pure cultures. The colonies were characterized morphologically (color, shape, elevation), subjected to GRAM staining and biochemical tests (catalase and oxidase). The bacteria were identified using identification kits (New Prov) in the UNISUL Biochemistry Laboratory (CENTEC), based on morphological and biochemical tests previously described by Silva et al. (2017).

The bacteria were then inoculated in brain heart infusion (BHI) to be later applied on bioreactors (batch) for evaluation in the industrial wastewater treatment using the parboiling process. The best results were obtained with the rice husk biomass.

Microorganisms were isolated from rice husk biomass as follows: rice husks were briefly washed under running water and incubated under anaerobic conditions at $37^{\circ} \mathrm{C}$ in a $15 \%$ ratio $\left(\mathrm{m} \mathrm{v}^{-1}\right)$. After incubation for $72 \mathrm{~h}$, the solution was separated from the rice husks and centrifuged for $5 \mathrm{~min}$ at 6000 $\mathrm{rpm}$. The supernatant containing water was discarded and the bacterial pellet was inoculated in a $250 \mathrm{~mL}$ flask containing distilled water. The bacterial pellet was then seeded on Blood Agar plates ( $0.5 \%$ of ovine blood) by exhaustion technique and incubated at $37^{\circ} \mathrm{C}$ for 24,48 , and $72 \mathrm{~h}$.

The control solution for microorganism propagation consisted of autoclaved rice husk biomass as the only source of carbon. The solution was incubated for $72 \mathrm{~h}$.

Rice husk samples were washed under running water and mixed with nitrogen contaminated water $\left(30 \mathrm{mg} \mathrm{N}-\mathrm{NO}_{3} \mathrm{~L}^{-1}\right)$ at $15 \%\left(\mathrm{~m} \mathrm{v}^{-1}\right)$ in $250 \mathrm{~mL}$ erlenmeyer flasks. The solution was kept under a dubnoff orbital shaking for specific times at 25 ${ }^{\circ} \mathrm{C}$. The control treatment consisted of sterilized biomass, autoclaved rice husks at $121{ }^{\circ} \mathrm{C}$ for $15 \mathrm{~min}$ before mixing in water contaminated with nitrate. The control treatment was performed in absence of external carbon source (rice husks). All assays were performed in triplicate.

The kinetic experiments to evaluate the nitrogen removal $\left(\mathrm{N}_{\text {Total }}\right.$ and $\left.\mathrm{N}-\mathrm{NO}_{3}\right)$ were performed in the laboratory in a batch system. Synthetic wastewater was prepared using deionized water and ammonium acetate (P.A., Merck) or sodium nitrate (P.A., Merck). Total nitrogen removal was evaluated using an ammonium acetate solution with concentration of $40 \mathrm{mg} \mathrm{L}^{-1}$ 
of nitrogen $\left(\mathrm{N}-\mathrm{NH}_{4}\right)$. N-NO $\mathrm{NO}_{3}$ removal was determined using a sodium nitrate solution with concentration of $30 \mathrm{mg} \mathrm{L}^{-1}$ of $\mathrm{N}-\mathrm{NO}_{3}$. The experiment was conducted in $250 \mathrm{~mL}$ erlenmeyer flasks at $25^{\circ} \mathrm{C}, \mathrm{pH} 7$ in a Dubnoff water bath, under constant stirring at $30 \mathrm{rpm}$. The aliquots were collected at intervals of 24,48 , and $72 \mathrm{~h}$, which were adequate times for the proposed treatment. The total nitrogen and nitrate analyses were evaluated in triplicates using a Spectroquant Merck spectrophotometer (PHARO 300, Test kit).

The reusability and performance of the $\mathrm{N}-\mathrm{NO}_{3}$ removal by the microorganisms were evaluated using a new inoculum prepared and kept incubated at $37^{\circ} \mathrm{C}$ for $72 \mathrm{~h}$. Then, $100 \mathrm{~mL}$ of the $30 \mathrm{mg} \mathrm{L}^{-1}$ of $\mathrm{N}-\mathrm{NO}_{3}$ solution with $3 \%\left(\mathrm{v} \mathrm{v}^{-1}\right)$ of the prepared inoculum was placed into erlenmeyer flasks at $25^{\circ} \mathrm{C}, \mathrm{pH} 7$ in a Dubnoff bath, under constant stirring at $30 \mathrm{rpm}$. An aliquot was collected every $24 \mathrm{~h}$ and the system was fed with $30 \mathrm{mg} \mathrm{L}^{-1}$ of $\mathrm{N}-\mathrm{NO}_{3}$ solution. This study lasted 7 days and all assays were performed in triplicate.

The conversion process was monitored through nitrate, total nitrogen, color, turbidity, sulfate, COD and solids analysis, as described in the Standard Methods for the Examination of Water and Wastewater (APHA, 2012) with analysis in spectrophotometer (spectrophotometer Spectroquant ${ }^{\circledR}$ Pharo 300 Merck) with a wavelength range of 190-1100 nm. The biochemical oxygen demand $\left(\mathrm{BOD}_{5}\right)$ was evaluated using Oxitop respirometers. The water $\mathrm{pH}$ was measured using a portable $\mathrm{pH}$ meter (Hanna). All assays were performed in triplicate.

\section{Results AND Discussion}

The main constituents of the rice husks were cellulose (34.61\% weight basis - wb), lignin (19.66\% wb), ash (16.82\% $\mathrm{wb})$, hemicellulose $(10.90 \% \mathrm{wb})$, and protein $(3.16 \% \mathrm{wb})$ (Table 1). The overall composition of the rice husks was similar to those of other studies (Chuah et al., 2005; Abbas \& Ansumali, 2010; Lim et al., 2012). However, the comparison with these other biomasses showed that the rice husks evaluated in the present study had lower cellulose, lignin, and hemicellulose contents, and relatively more protein content.

The results of the microorganism production over time with the different biomasses are presented in Table 2. The industrial

Table 1. Chemical composition of the rice husk biomass

\begin{tabular}{|lc|}
\hline Constituents & \% weight basis \\
\hline Cellulose & $34.61 \pm 3.35$ \\
\hline Lignin & $19.66 \pm 2.40$ \\
\hline Ashes & $16.82 \pm 1.80$ \\
\hline Hemicellulose & $10.90 \pm 1.55$ \\
\hline Moisture & $6.42 \pm 1.10$ \\
\hline Extractives & $3.17 \pm 0.68$ \\
\hline Protein & $3.16 \pm 0.45$ \\
\hline
\end{tabular}

Table 2. Evolution of microbial growth using different biomasses and industrial wastewater (IW)

\begin{tabular}{ccccc}
\hline \multirow{2}{*}{$\begin{array}{c}\text { Time } \\
\text { (h) }\end{array}$} & IW & $\begin{array}{c}\text { IW }+ \\
\text { rice husk* }\end{array}$ & $\begin{array}{c}\text { IW }+ \\
\text { sawdust* }^{*}\end{array}$ & $\begin{array}{c}\text { IW + dried leaves } \\
\text { of trees* }\end{array}$ \\
\cline { 2 - 5 } (CFU mL-1) $^{*}$ & - & - \\
0 & - & - & - & $1.08 \times 10^{5}$ \\
24 & $1.12 \times 10^{4}$ & $6.96 \times 10^{7}$ & $2.22 \times 10^{4}$ & $1.08 \times 10^{5}$ \\
48 & $1.64 \times 10^{4}$ & $8.50 \times 10^{7}$ & $2.32 \times 10^{4}$ & $2.50 \times 10^{5}$ \\
72 & $2.71 \times 10^{4}$ & $11.20 \times 10^{7}$ & $3.96 \times 10^{4}$ & $4.20 \times 10^{5}$ \\
\hline
\end{tabular}

CFU - Colony forming unity; ${ }^{\star} 15 \%$ wb of the respective biomass was added; IW: Industrial wastewater

wastewater (IW) was used to evaluate microbial growth propagation. The wastewater without addition of biomasses also showed microbial growth. This was due to the presence of nutrients in the raw wastewater from the rice processing. The wastewater from rice parboiling can promote microbial growth, even without additional biomass.

Nevertheless, the addition of biomass (15\% wb) enhanced microbial growth, especially when rice husks was used as substrate. The better performance of rice husks was probably due to its chemical composition (Table 1), which favored microbial growth. The lack of nitrogen source and excessive lignin content of the other tested biomasses may have hindered microbial growth, causing nutrient deficiency and formation of inhibitor by-products due to lignin degradation, respectively (Negi, 2012; Asina et al., 2017). Moreover, sawdust and dried leaves may release phenolic compounds when are in contact with water, which also inhibits microbial activity (Rauha et al., 2000; Cushnie \& Lamb, 2011; Negi, 2012;).

The most important bacteria produced in the rice husk biomass were identified and characterized (Table 3), which were probably Oerskovia spp. (Gram positive Bacilli), Enterococcus sp. (Gram positive Cocci), Bacillus mycoide (Gram positive Bacilli), and Escherichia coli (Gram negative Bacilli). These bacteria have the unusual property of responding to variations by their mechanical strength on the surface structure of the growth medium with the formation of a biofilm. These biofilms, when organized transversely by a set of bacteria, may be responsible for the process of removal of contaminants (organic compounds and nitrogen) from wastewaters.

The untreated wastewater presented a high concentration of organic matter (Table 4), with averages of $4884 \mathrm{mg} \mathrm{L}^{-1}$ for COD, and $1600 \mathrm{mg} \mathrm{L}^{-1}$ for $\mathrm{BOD}_{5}$. High values for color $(220 \mathrm{~Hz})$ and turbidity (176 FAU) were also observed. Color and turbidity are indicators of wastewater quality and are often interconnected. Thus, high contamination levels can be related to high color and turbidity values (Simões et al., 2008). The nitrogen ( $\mathrm{N}_{\text {Total' }}$, $\left.56.04 \mathrm{mg} \mathrm{L}^{-1}\right)$ and nitrate $\left(\mathrm{N}-\mathrm{NO}_{3}, 7.4 \mathrm{mg} \mathrm{L}^{-1}\right)$ contents were significant. The nitrogen content may be mainly related to the presence of protein and acidogenic loads (nucleic acid) from the organic matter of vegetable origin. Similar results were

Table 3. Characterization of microorganisms produced in the rice husk biomass

\begin{tabular}{|c|c|c|c|c|c|}
\hline Bacteria & Gram stain test & Oxidase & Catalase & $\begin{array}{l}\text { Hemolysis } \\
\text { in blood agar }\end{array}$ & Morphology \\
\hline Oerskovia spp. & Positive Bacilli & Negative & Positive & Variable & Yellow colony \\
\hline Enterococcus sp. & Positive Cocci & Negative & Negative & Negative & Punctiformy colony \\
\hline Bacillus mycoide & Positive Bacilli & Negative & Positive & Beta & Rhizoid colony \\
\hline Escherichia coli & Negative Bacilli & Negative & Positive & Positive & Wet colony, white/transparent \\
\hline
\end{tabular}


Table 4. Parameters analyzed for rice parboiling wastewater untreated and treated with $3 \%$ (volume basis - vb) of the inoculum (microorganisms) obtained from rice husks

\begin{tabular}{lccc}
\hline \multicolumn{1}{c}{ Variables } & Wastewater & $\begin{array}{c}\text { Treated } \\
\text { wastewater }\end{array}$ & $\begin{array}{c}\text { Removal } \\
\text { efficiency (\%) }\end{array}$ \\
$\mathrm{pH}$ & $5.5 \pm 0.1$ & $6.4 \pm 0.2$ & - \\
Color $(\mathrm{Hz})$ & $220 \pm 14$ & $78 \pm 4$ & 64.50 \\
Turbidity (FAU) & $176 \pm 8$ & $64 \pm 3$ & 63.60 \\
$\mathrm{COD}\left(\mathrm{mg} \mathrm{L}^{-1}\right)$ & $4,884 \pm 132$ & $1050 \pm 53$ & 78.50 \\
$\mathrm{BOD}_{5}\left(\mathrm{mg} \mathrm{L}^{-1}\right)$ & $1,600 \pm 58$ & $480 \pm 10$ & 70.00 \\
$\mathrm{~N}^{-} \mathrm{NO}_{3}\left(\mathrm{mg} \mathrm{L}^{-1}\right)$ & $7.40 \pm 1.2$ & $3.4 \pm 0.2$ & 54.05 \\
$\mathrm{~N}_{\text {Total }}\left(\mathrm{mg} \mathrm{L}^{-1}\right)$ & $56.04 \pm 8$ & $9.5 \pm 2$ & 83.04 \\
Sulfate $\left(\mathrm{mg} \mathrm{L}^{-1}\right)$ & $6.70 \pm 0.9$ & $0.8 \pm 0.3$ & 88.05 \\
Suspended solids (mg L-1) & $302 \pm 12$ & $31 \pm 4$ & 89.70 \\
Total solids (mg L-1) & $23,426 \pm 185$ & $128 \pm 10$ & 99.45 \\
\hline BoD
\end{tabular}

BOD = Biochemical Oxygen Demand; COD = Chemical Oxygen Demand

found in studies with wastewater from parboiled rice process employed as a medium for microalgae and cyanobacteria growth (Mukherjee et al., 2016).

All analyzed variables had, in general, average efficiency above $60 \%$ (Table 4 ) in the removal of contaminants. The greatest reductions were found for the removal of total solids (99.45\%), suspended solids (89.70\%), sulfate $(88.05 \%), \mathrm{N}_{\text {Total }}$ $(83.04 \%), \mathrm{COD}(78.50 \%)$, and $\mathrm{BOD}_{5}(70 \%)$. The average color value was reduced from 220 to $78 \mathrm{~Hz}$, and the turbidity from 176 to 64 FAU, representing an effective removal of approximately $64 \%$ of the organic matter from the degradation of the plant residue (rice rusks).

Two experiments were conducted using different wastewaters and decreasing inoculum concentration up to $1 \%$ $\left(\mathrm{v} \mathrm{v}^{-1}\right)$ to evaluate the efficiency of the inoculum.

The carbon and nitrogen organic matter decreased in both analyzed samples, industrial and synthetic wastewater (Figure 1). However, the samples that presented the best removals for the $\mathrm{N}_{\text {Total }}$ and $\mathrm{BOD}_{5}$ were from the industrial wastewater, with reductions of 47.62 and $54.79 \%$, respectively. However, the average removal of COD was $42 \%$. These results were probably obtained because this type of wastewater already presented some nutrients in its composition.

An increase in microorganism concentration (active cells) in the medium was observed by the end of the experiment. The control treatment in absence of inoculum did not reduce the analyzed variables $\left(\mathrm{N}_{\text {total }}, \mathrm{COD}, \mathrm{BOD}_{5}\right)$.

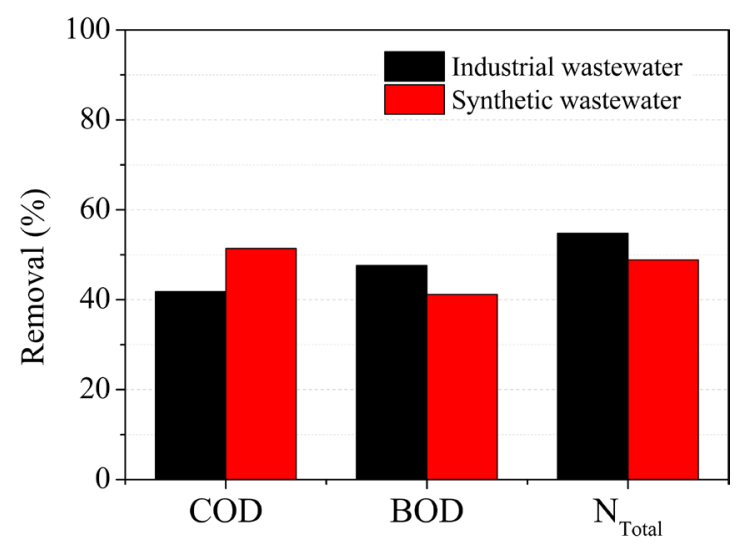

$\mathrm{BOD}_{5}$ - Biochemical Oxygen Demand; COD - Chemical Oxygen Demand

Figure 1. Removal of organic matter and total nitrogen from industrial and synthetic wastewaters after 72 hours, using $1 \%$ (vb) of inoculum of microorganisms
The period of greatest removal of $\mathrm{N}$ was up to $24 \mathrm{~h}$ of the experiment, in which $\mathrm{N}_{\text {Total }}$ was reduced from 40 to $25 \mathrm{mg} \mathrm{L}^{-1}$, and $\mathrm{N}-\mathrm{NO}_{3}$ from 30 to $18 \mathrm{mg} \mathrm{L}^{-1}$, representing removals of about $40 \%$ (Figure 2).

This was expected, since more nutrients are available to microorganisms at the beginning of the test, and a higher $\mathrm{N}$ concentration induces the microbial activity (Shuler \& Kargi, 1992). Therefore, the rate of removal decreases progressively until reaching the equilibrium state $(\sim 80 \%$ of removal) after $72 \mathrm{~h}$.

The evaluation of the reusability through continuous process of the microorganism inoculum is shown in Figure 3.

The removal of $\mathrm{N}-\mathrm{NO}_{3}$ during the 7 days of experiment showed that the microorganisms present a stable performance when fed with the same amount of substrate. The results were consistent to those previously discussed, with a removal around $80 \%$ of the initial $\mathrm{N}-\mathrm{NO}_{3}$ load. Therefore, the microorganisms produced from the rice husks have great potential to be employed on nitrogen removal from wastewaters.

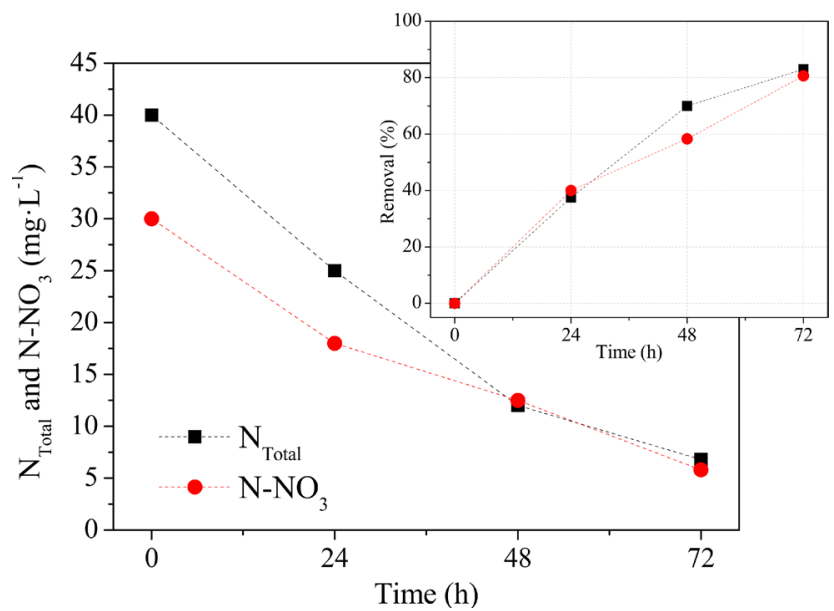

Figure 2. Concentration ( $\left.\mathrm{mg} \mathrm{L}^{-1}\right)$ and removal (\%) of total nitrogen and nitrate nitrogen over time, using $3 \%(\mathrm{vb})$ of inoculums of microorganisms

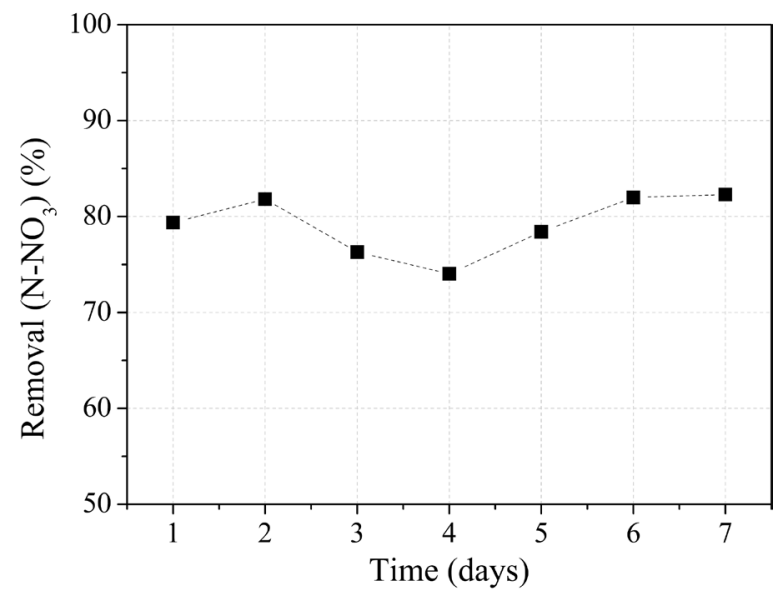

Figure 3. Continuous process test of the microorganism inoculum $(3 \% \mathrm{vb})$ for the removal of $\mathrm{N}-\mathrm{NO}_{3}$ (batch concentration of $30 \mathrm{mg} \mathrm{L}^{-1}$ )

\section{Conclusions}

1. Rice husks is a promising biomass source for growing of microorganisms capable of treating wastewater. 
2. The optimal amount and conditions for microorganism cultivation was $15 \%\left(\mathrm{~m} \mathrm{v}^{-1}\right)$ of rice husks at $25{ }^{\circ} \mathrm{C}$ for $72 \mathrm{~h}$. In general, the average efficiency of contamination removal exceeded $60 \%$.

3. The variables total solid, $\mathrm{N}_{\text {Total }}, \mathrm{COD}$, and $\mathrm{BOD}_{5}$ contents decreased in $99,80,78$, and $70 \%$, respectively, when using inoculations with $3 \%\left(\mathrm{v} \mathrm{v}^{-1}\right)$ of microorganisms obtained from rice husks as substrate.

4. The inoculum presented a stable and continuous activity even after 7 days of the batch experiment, denoting the potential and reproducibility of nitrate removal.

\section{ACKNOWLEDGMENTS}

The authors thank the Universidade do Sul de Santa Catarina, Fundação de Amparo à Pesquisa e Inovação do Estado de Santa Catarina, and Conselho Nacional de Desenvolvimento Científico e Tecnológico for the financial support to this project.

\section{Literature Cited}

Abbas, A.; Ansumali, S. Global potential of rice husks as a renewable feedstock for ethanol biofuel production. Bioenergy Research, v.3, p.328-334, 2010. https://doi.org/10.1007/s12155-010-9088-0

ABNT - Associação Brasileira de Normas Técnicas. NBR 9897 Planejamento de amostragem de efluentes líquidos e corpos receptores. Rio de Janeiro: ABNT, 1987a. 14p.

ABNT - Associação Brasileira de Normas Técnicas, 1987b. NBR 9898 - Preservação e técnicas de amostragem de efluentes líquidos e corpos receptores. Rio de Janeiro: ABNT, 1987b. 22p.

Akinyele, J. B.; Adetuyi, C. F. Effect of agrowastes, $\mathrm{pH}$ and temperature variation on the growth of volvariella volvacea. African Journal of Biotechnology, v.4, p.1390-1395, 2005.

APHA - American Public Health Association. Standard methods for the examination of water and wastewater. 22th ed., American Public Health Association: New York, 2012.

Asina, F.; Brzonova, I.; Kozliak, E.; Kubátová, A.; Ji, Y. Microbial treatment of industrial lignin: Successes, problems and challenges. Renewable and Sustainable Energy, v.77, p.1179-1205, 2017. https://doi.org/10.1016/j.rser.2017.03.098

Bartucca, M. L.; Mimmo, T.; Cesco, S.; Buono, D. del. Nitrate removal from polluted water by using a vegetated floating system. Science of the Total Environment, v.542, p.803-808, 2016. https://doi. org/10.1016/j.scitotenv.2015.10.156

Chuah, T. G.; Jumasiah, A.; Azni, I. ; Katayon, S.; Choong, S. Y. T. Rice husks as a potentially low-cost biosorbent for heavy metal and dye removal: An overview. Desalination, v.175, p.305-316, 2005. https://doi.org/10.1016/j.desal.2004.10.014

Costa, D. D. ; Gomes, A. A.; Fernandes, M. ; Bortoluzzi, R. L. da C.; Magalhães, M. de L. B.; Skoronski, E. Using natural biomass microorganisms for drinking water denitrification. Journal of Environmental Management, v.217, p.520-530, 2018. https://doi. org/10.1016/j.jenvman.2018.03.120

Cushnie, T. P. T.; Lamb, A. J. Recent advances in understanding the antibacterial properties of flavonoids. International Journal of Antimicrobial Agents, v.38, p.99-107, 2011. https://doi. org/10.1016/j.ijantimicag.2011.02.014
Huang, C.; Luo, M.-T.; Chen, X.-F.; Xiong, L.; Li, X. M.; Chen, X. D. Recent advances and industrial viewpoint for biological treatment of wastewaters by oleaginous microorganisms. Bioresource Technology, v.232,p.398-407, 2017.https://doi.org/10.1016/j.biortech.2017.02.055

Hulle, S. W. H. van; Vandeweyer, H. J. P.; Meesschaert, B. D.; Vanrolleghem, P. A.; Dejans, P.; Dumoulin, A. Engineering aspects and practical application of autotrophic nitrogen removal from nitrogen rich streams. Chemical Engineering Journal, v.162, p.120, 2010. https://doi.org/10.1016/j.cej.2010.05.037

João, J. J.; Satiro, Jr. W.; Vieira, J. L. Use of zeolite synthesized from coal ashl from Santa Catarina for removal of iron, manganese and methylene blue dye in water. Revista Ambiente \& Água v.13, p.2224-2241, 2018. https://doi.org/10.4136/ambi-agua.2224

Khan, S. T.; Malik, A. Engineered nanomaterials for water decontamination and purification: From lab to products. Journal of Hazardous Materials, v.363, p.295-308, 2019. https:// doi.org/10.1016/j.jhazmat.2018.09.091

Lim, J. S.; Manan, Z. A.; Alwi, S. R. A.; Hashim, H. A review on utilisation of biomass from rice industry as a source of renewable energy. Renewable and Sustainable Energy Reviews, v.16, p.30843094, 2012. https://doi.org/10.1016/j.rser.2012.02.051

Low, E. W.; Chase, H. A. Reducing production of excess biomass during wastewater treatment. Water Research, v.33, p.1119-1132, 1999. https://doi.org/10.1016/S0043-1354(98)00325-X

Mukherjee, C.; Chowdhury, R.; Sutradhar, T.; Begam, M. Ghosh, S. M.; Basak, S. K.; Ray, K. Parboiled rice effluent: A wastewater niche for microalgae and cyanobacteria with growth coupled to comprehensive remediation and phosphorus biofertilization. Algal Research, v.19, p.225-236, 2016. https://doi.org/10.1016/j.algal.2016.09.009

Negi, P. S. Plant extracts for the control of bacterial growth: Efficacy, stability and safety issues for food application. International Journal of Food Microbiology, v.156, p.7-17, 2012. https://doi. org/10.1016/j.ijfoodmicro.2012.03.006

Rauha, J. P.; Remes, S.; Heinonen, M.; Hopia, A.; Kähkönen, M.; Kujala, T.; Vuorela, P. Antimicrobial effects of Finnish plant extracts containing flavonoids and other phenolic compounds. International Journal of Food Microbiology, v.56, p.3-12, 2000. https://doi.org/10.1016/S0168-1605(00)00218-X

Shen, Z.; Yin, Y.; Wang, J. Biological denitrification using poly (butanediol succinate) as electron donor. Applied Microbiology and Biotechnology, v.100, p.6047-6053, 2016. https://doi.org/10.1007/s00253-016-7435-6

Shuler, M.; Kargi, F. Bioprocess engineering: Basic concepts. 3.ed. Prentice hall: Cornel University, 1992. 656p.

Silva, N.; Junqueira, V. C. A.; Silveira, N. F. A.; Silveira, N. F. A.; Taniwaki, M. H.; Gomes, R. A. R.; Okazaki, M. M. Manual de métodos de análise microbiológica de alimentos e água. 5.ed. São Paulo: Blucher, 2017. 535p.

Simões, F. dos S.; Moreira, A. B.; Bisinoti, M. C.; Gimenez, S. M. N.; Yabe, M. J. S. Water quality index as a simple indicator of aquaculture effects on aquatic bodies. Ecological Indicators, v.8, p.476-484, 2008. https://doi.org/10.1016/j.ecolind.2007.05.002

Soest, P. J. van; Robertson, J. B.; Lewis, B. A. Methods for dietary fiber, neutral detergent fiber, and nonstarch polysaccharides in relation to animal nutrition. Journal of Dairy Science, v.74, p.3583-3597, 1991. https://doi.org/10.3168/jds.S0022-0302(91)78551-2

Yang, X. L.; Jiang, Q. ; Song, H. L.; Gu, T. T.; Xia, M. Q. Selection and application of agricultural wastes as solid carbon sources and biofilm carriers in MBR. Journal of Hazardous Materials, v.283, p.186-192, 2015. https://doi.org/10.1016/j.jhazmat.2014.09.036 